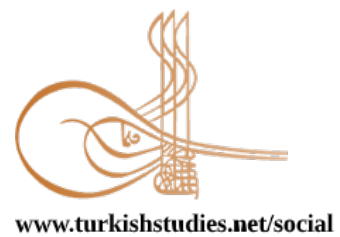

Turkish Studies - Social Sciences

eISSN: 2667-5617

Research Article / Araştırma Makalesi

\title{
Sağlık Hizmetleri Meslek Yüksekokulu Yöneticilerinin Dönüşümcü ve Etkileşimli Liderlik Algılarının Değerlendirilmesi
}

\author{
Evaluation of Transformational and Transactional Leadership Perceptions of Health Services \\ Vocational School Managers
}

\author{
Mustafa Filiz - Sait Bardakçı*
}

\begin{abstract}
This study was carried out to determine multiple leadership style perception level and general leadership perception level of academics in management positions in Health Services Vocational Schools in Turkey and whether this perceptions vary according to some determined variables. The universe of the study is composed of academics in management positions in Health Services Vocational Schools in Turkey. The sample of the study consists of 87 academicians who take charge in the management level in Health Services Vocational Schools that accept to participate in the study voluntarily. In the research, questionnaire was used as a data collection tool. General leadership perception scale, multiple leadership scale and six demographic questions were used in the questionnaire. Mann-Whitney U and Kruskal-Wallis tests were used in the analysis of the data. Bonferroni correction was taken into consideration in determining the level of significance in the Mann-Whitney $U$ tests performed for binary comparisons of variables with significant differences compared to the Kruskal-Wallis test. According to the findings obtained in the research, $60.9 \%$ of healthcare vocational school administrators stated that they see themselves as leaders, while $34.5 \%$ state that they define themselves as a partial leader. Overall, all positive multiple leadership sub-dimension scores of managers were found to be high. In the research, significant differences were determined in the multiple leadership sub-dimensions according to age, gender, year of employment, administrative position, marital status and academic title. As a result of the research, it has been determined that the administrative academicians, who generally works in the management level of vocational schools of health services, are open to change and development and have a positive approach.
\end{abstract}

Structured Abstract: Throughout history, some people gained superiority over other people and managed to drag the society behind them. One needs a group to satisfy their own wishes and desires and feels the need to act with the group. Creating a certain group, mobilizing it within a target and maintaining continuity requires superior skills that are not available to every person (Demir et al., 2010: 132; Üstün, 2014: 1). Efforts to

\footnotetext{
* Öğr.Gör, Artvin Çoruh Üniversitesi, Sağlık Hizmetleri MYO, Tıbbi Hizmetler ve Teknikler Bölümü Lecturer, Artvin Coruh University, Health Services Vocational School, Department of Medical Services and Techniques ORCID 0000-0002-7445-5361 mustafafiliz1109@gmail.com ** Dr.Öğretim Üyesi, Cumhuriyet Üniversitesi, İIBF, İşletme Bölümü

Asst. Prof., Cumhuriyet University, Faculty of Economics and Administrative Sciences, Departmen of Business ORCID 0000-0003-3720-5029

sait_bardakci@hotmail.com

Cite as/ Atıf: Filiz, M., Bardakçı, S. (2020). Sağlık hizmetleri meslek yüksekokulu yöneticilerinin dönüşümcü ve etkileşimli liderlik algılarının değerlendirilmesi. Turkish Studies - Social, 15(4), 1891-1918. https://dx.doi.org/10.29228/TurkishStudies.43412

Received/Geliş: 06 May/Mayıs 2020

Accepted/Kabul: 20 June/Haziran 2020

Copyright $(\mathrm{C}$ INTAC LTD, Turkey

Checked by plagiarism software

Published/Yayın: 25 June/Haziran 2020

CC BY-NC 4.0
} 
reflect these behaviors, which are generally referred to as leadership characteristics, to the stakeholders of different organizations and institutions, remain current.

Many researchers predict that the leadership style of the organization manager is an important variable on the behavior of those working in the organization (Cansu and Polatcan, 2019: 15). There are many studies in the literature on how managers' leadership styles affect organizational performance and employee behavior. In general, in these studies include motivation of employees, organizational trust, organizational commitment, organizational citizenship, justice, etc., it is observed that it is aimed at determining the perception levels of empolyees (Ar1, 2003; Akbolat et al., 2013; Örücü and Teker, 2014; Örgev and Sütlü, 2018; Kırkpınar and İşcan, 2018).

This study was carried out to determine multiple leadership style perception level and general leadership perception level of academics in management positions in Health Services Vocational Schools in Turkey and whether this perceptions vary according to some determined variables. In the literature, there is no study conducted for this target audience determined in the study. It is thought that the study has an original value in this respect and will contribute to the literature.

The universe of the study is composed of academics in management positions in in Health Services Vocational Schools in Turkey. The sample consists of 87 academics who voluntarily agreed to participate in the study. convenience sampling method was used in determining the sample of the research. Questionnaire was used as a data collection tool in research. General leadership perception scale, multiple leadership scale and six demographic questions were used in the questionnaire.

The distribution of the answers given by the managers of the health vocational school to the statements directed to determine their general leadership perception about them was analyzed using frequency tables and descriptive statistics. Kolmogorov-Smirnov test was conducted to determine whether the Multifactor Leadership Scale sub-dimension mean scores were normally distributed. As a result of the test, it was observed that the Multifactor Leadership Scale sub-dimension mean scores did not show normal distribution, and it was concluded that nonparametric statistical methods would be appropriate in the analysis of the data considering the sample size. In this context, Mann-Whitney U and Kruskal-Wallis tests were used to analyze the data. Bonferroni correction was taken into consideration in determining the level of significance in the Mann-Whitney U tests performed for binary comparisons of variables with significant differences compared to the Kruskal-Wallis test. IBM SPSS 25 package program was used in the analysis.

According to the main findings of the research, firstly, it was found that the Laissez-Faire and management with exceptions (passive) subscale mean scores were low, management with exceptions (active) subscale mean scores were at medium-level and other sub-dimensions' subscale mean scores were high. Also, $60.9 \%$ of the managers of Vocational School of Health stated that they see themselves as leaders, while $34.5 \%$ state that they define themselves as a leader partially.

The mean scores of the management with exceptions (passive) sub-dimension of health vocational school managers showed a significant difference according to gender $(p<0.05)$. Considering the median values belonging to gender groups with this situation, it was seen that the average scores of the management with exceptions (passive) sub-dimensions of male managers are higher than the female managers. It was found that all the other multiple leadership sub-dimension mean scores did not differ significantly according to the gender variable $(\mathrm{p}>0.05)$.

The transformational leadership intellectual stimulation sub-dimension and interactive leadership conditional reward sub-dimension of health vocational school managers differed significantly from their marital status $(p<0.05)$. Considering the median values of married and single managers, it can be said that the intellectual stimulation and conditional reward subscale mean scores of married managers are significantly higher than that of single managers. Other multi-leadership sub-dimensional mean scores did not differ significantly from the marital status of the managers $(\mathrm{p}>0.05)$. Also, it was determined that the scores of ideal effects, motivation and effectiveness attributed to the managers of the health vocational school were significantly higher than both the vice-managers and the department heads. In Laissez Faire subdimension scores, the average scores of the managers were found to be significantly lower than both the vicemanagers and the department heads.

The administrative staff at the universities are fully responsible for the academic and administrative functioning of the institution, but also has the authority to develop and carry out educational policies such as 
determining the course contents and academic activities. In this sense, they are leaders in the institution they are managers of. Based on these thoughts, this study was carried out for managers who are considered to have significant authority and responsibility on academic and administrative functioning in healthcare vocational high schools.

Considering all the findings of the study, when a general conclusion is reached, the leadership behavior, transformational leadership and interactive leadership levels of academicians in the vocational school of health services were observed at a high level. In this context, it has been observed that managers generally have a leadership profile that is open to change and development, within a positive approach.

It is thought that it would be beneficial to carry out such studies with a larger sample in different faculties and vocational schools. With the new studies to be carried out, it is thought that determining the leadership styles of academicians who are in the administrative staff of universities and subunits of universities and examining their relationship with different variables will also contribute to the literature.

Keywords: Leadership, Leadership Styles, Transformational Leadership, Interactive Leadership, Vocational School.

Öz: Bu çalışma Türkiye'de sağlık hizmetleri meslek yüksekokullarında görev yapan yöneticilerin, çoklu liderlik stiline yönelik algı düzeyleri ile genel liderlik algı düzeylerini belirlemek ve bunların belirlenen bazı değişkenlere göre farklılık arz edip etmediğini tespit etmek amacıyla yapılmıştır. Çalışmanın evreni, Türkiye'de sağlık hizmetleri meslek yüksekokullarında yönetim kademesinde bulunan akademisyenlerden meydana gelmektedir. Araştırmanın örneklemi ise çalışmaya gönüllü olarak katılmayı kabul eden sağlık meslek yükselokullarında yönetim kademesinde görev alan 87 akademisyenden oluşmaktadır. Araştırmada veri toplama aracı olarak anket kullanılmıştır. Ankette, genel liderlik algı ölçeği, çok faktörlü liderlik ölçeği ve altı adet demografik soru kullanılmıştır. Verilerin analizinde Mann-Whitney U ve Kruskal-Wallis testleri kullanılmıştır. Kruskal-Wallis testine göre anlamlı farklılık tespit edilen değişkenlerin ikili karşılaştırmaları için yapılan Mann-Whitney U testlerinde önem seviyesinin belirlenmesinde Bonferroni düzeltmesi dikkate alınmıştır. Araştırmada elde edilen bulgulara göre sağlık hizmetleri meslek yüksekokulu yöneticilerinin \%60.9'u kendisini lider olarak gördüğünü ifade ederken \%34.5'i kendisini kısmen bir lider olarak tanımladığını ifade etmektedir. Genel itibariyle yöneticilerin tüm olumlu çoklu liderlik alt boyut puanlarının yüksek düzeyde olduğu görülmüştür. Araştırmda yaş, cinsiyet, çalışma yılı, idari görev, medeni durum ve akademik unvan değişkenlerine göre çoklu liderlik alt boyutlarında anlamlı farklılıklar tespit edilmiştir. Araştırma sonucunda genel olarak sağlık hizmetleri meslek yüksekokullarının yönetim kademesinde görev alan yönetici akademisyenlerin değişim ve gelişime açık, pozitif yaklaşım içerisinde oldukları belirlenmiştir.

Anahtar Kelimeler: Liderlik, Liderlik Stilleri, Dönüşümcü Liderlik, Etkileşimli Liderlik, Meslek Yüksekokulu.

\section{Giriş}

Tarih boyunca bir kısım insanlar, diğer insanlara karşı üstünlük elde etmiş ve toplumu arkasından sürüklemeyi becermiştir. Kişi kendi istek ve arzularını tatmin etmek amacıyla başka insanların yardımına muhtaç olup onlarla uyumlu yaşama gereği hisseder. Belirli bir grubu olușturup, bir hedef çerçevesinde harekete geçirip ve devamlılık sağlamak her insanda olmayan üstün yetenekler gerektirmektedir (Demir vd., 2010:132; Üstün, 2014: 1). Genel olarak liderlik özellikleri olarak tabir edilen bu davranışların farklı örgüt ve kurumların paydaşlarına yansımasına yönelik çalışmalar güncelliğini korumaktadır.

Birçok araştırmacı örgüt yöneticisinin liderlik stilinin, örgütte çalışanların davranışları üzerinde önemli bir değişken olduğunu öngörmektedir (Cansu ve Polatcan, 2019: 15). Literatürde yöneticilerin liderlik stillerinin örgüt performansı ve çalışan davranışlarını nasıl etkilediğine dair birçok çalışma bulunmaktadır. Bu çalışmaların genel olarak liderlik stilinin çalışanları motivasyon, işten ayrılma, örgütsel güven, örgütsel bağl1lık, örgütsel vatandaşlık, adalet vb. alg1 düzeylerini belirlemeye yönelik olduğu görülmektedir (Arı, 2003; Akbolat vd., 2013; Örücü ve Teker, 2014; 
Örgev ve Sütlü, 2018; Kırkpınar ve İşcan, 2018). Diğer yandan bir kısım çalışmaların ise eğitim ve sağlık kurumlarına yönelik olarak üniversite öğrencilerine, öğretmenlere, sağlık çalışanlarına vb. gruplara yönelik yapıldığı görülmektedir (Barbuto, 2005; Buluç, 2009; Cemaloğlu ve Okçu, 2012; Atılgan, 2013; Aydın vd., 2013).

Üniversiteler bilgiyi uygulamanın, yaratıcılığın, farklı sesliliğin, değişim ve dönüşümün öncüsü durumundadır. Üniversitelerin bu fonksiyonlarını hakkıyla ifa edilebilmesi için tartışma ve özgür bir eleştiri kültürünün varlığı büyük önem arz etmektedir (Durak, 2012). Bu bağlamda üniversitelerde akademik birimlerde yönetici konumunda olan kişilerin sıralanan sorumluluklarını ne düzeyde yönetim süreçlerinde yerine getirdiklerinin, ne tip liderlik özelliklerine sahip olduklarının ve yöneticilerin hangi liderlik davranışlarını daha çok sergilediklerinin belirlenmesi önem arz etmektedir. Üniversite birimlerinin görevlerini gerçekleştirirken idari konumda yer alan akademisyenlerin liderlik tarzları önemli oranda etkili olmaktadır. Üniversite yöneticilerinin örgütsel yapıyı kurma, yönetme ve çalışanlarıyla olan ilişkilerinde ne düzeyde verimli olduklarının belirlenmesi, üniversitelerin verimli işleyişine dair önemli bilgiler sunacaktır.

Literatürde farklık kurumlarda görev alan yöneticilerin liderlik stillerini belirlemeye yönelik birçok çalışma yapıldığı görülmüştür. Bu çalışma ise Türkiye'deki üniversitelerde Sağlık Hizmetleri Meslek Yüksekokullarında görev yapan yöneticilerin genel liderlik alg1 düzeylerini, çoklu liderlik stiline yönelik algı düzeylerini ve bunların bir kısım değişkenlere göre farklılık arz edip etmediğini belirlemek amacıyla yapılmıştır. Sağlık hizmetleri meslek yüksekokulları, sağlık sektöründe çalışacak ara elamanları yetiştirmesi sebebiyle sektörün işleyişinde önemli bir role sahiptir. Dolayısıyla kurum yöneticilerinin göstereceği yönetim performansının ve liderlik özelliklerinin kurumun amaçlarına ulaşmasında ve sağlık sektörüne olumlu katkılar sunulmasında önemli bir faktör olduğu düşünülmektedir. Bu yüzden araştırmada hedef kitle olarak sağlık hizmetleri meslek yüksekokulu yöneticileri tercih edilmiştir. Literatürde, araştırmada belirlenen hedef kitleye yönelik bu amaçla yapılan benzer bir çalışmaya rastlanmamıştır. Araştırmanın bu yönden özgün olduğu ve literatüre katkı sağlayacağı öngörülmektedir.

\section{Kavramsal Çerçeve}

Bu bölümde çalışmanın amacına uygun olarak, öncelikle lider ve liderlik kavramlarının tanımları yapılmış, daha sonra sadece çalışmada incelenen liderlik stilleri ve alt boyutları açıklanmıştır.

\section{Liderlik ve liderlik stilleri}

Liderlik kavramının ortaya çıkmasının insanlık tarihinin başlamasıyla birlikte olduğu düşünülmektedir. Bir yerde iki veya daha fazla insan varsa ve bunlardan biri izlenen konumunda ise o kişi liderdir (Liu, 2015: 476). Literatürde liderlik ile ilgili birçok tanım bulunmaktadır. Liderlik, bir amacın gerçekleşmesi için bireylerde olması gereken isteği ve başarı dürtüsünü harekete geçirmek amacıyla kişileri etkileme sürecidir (Koontz vd., 1999: 451). Bir başka tanıma göre liderlik, ortak bir amaca ulaşmak için bireylerin davranışlarını yönetip yönelten liderin faaliyetidir (Karahan, 2008: 18). Bir başka tanıma göre ise liderlik, belli şartlar içerisinde tanımlanmış bireysel ya da grup hedeflerinin gerçekleşmesi için bireyin başkalarını etkilemesi ve idare edebilmesidir (Koçel, 2007).

Dönüşümcü (Transformasyonel) liderlik: $\mathrm{Bu}$ liderlik stili, beklenilen değişimin gerçekleşmesi adına liderin ve takipçilerin ortak bir amaç ve misyon etrafında birleşmesinin sağlanması için etkileyici bir vizyonla harekete geçilmesini ifade etmektedir. Bu liderlik stilinde lider, izleyici ve çalışanları etkilemek için adaleti, insani değerleri, özgürlüğü vb. üstün değerleri öne çıkarmaktadır (Kırel, 2001: 46). Dönüşümcü liderliğin telkinle güdüleme, idealleştirilmiş etki, bireysel destek ve entelektüel uyarım olmak üzere dört alt boyutu bulunmaktadır (Üstün, 2014: 22). 
Telkinle güdüleme: Dönüşümcü liderler, çalışanlarına pozitif bakış açısı kazandırıp yaşama tutkularını yükseltmektedirler. Lider hedeflere sıkı sıkı bağlıdır. Bu durum çalışanlara büyük motive sağlamaktadır (Scandura ve Williams, 2004: 451).

İdealleştirilmiş etki: Dönüşümcü liderler, çalışanlarıyla amaç ve hedefleri paylaşır. Problemlere karşı büyük ve yenilikçi yaklaşımlar ortaya koyar. Çalışanlar, lidere güvenmektedirler ve onunla özdeşleşmek isterler (Stewart, 2006: 12).

Bireysel destek: Lider, her bir çalışanını ayrı bir dünya olarak değerlendirir Her birine ayrı bir ilgi ve koçluk hizmeti vermeye çaba gösterir (Bass, 1997: 22).

Entelektüel uyarım: Lider, çalışanların yeni beceri ve düşünceleri kazanması için firsatlar sunar. Problemlerin yeni yöntemlerle çözüme kavuşması için çalışanları teşvik eder (Stewart, 2006: 12).

Özet olarak dönüşümcü lider takipçilerini anlayan, onlara kişisel gelişim imkânı veren, radikal değişime gidebilen, çalışanlar üzerinde büyük değişimler sağlayan ve geleceğe yönelik olarak hareket eden kişilerdir (Barl1, 2010: 370).

Etkileşimli (Transaksiyonel) liderlik: Bu tip liderler takipçilerini ödüllerle etkilemeyi, örgütün kurallarına bağlı kalmayı ve bunu çalışanlardan da beklemeyi esas tutan bir yönetim anlayışı içindedirler. Dolayısıyla bu tarz liderler, örgütsel hedeflere ulaşmayı ve bunu gerçekleștiren çalışanı ödüllendirmeyi temel bir amaç olarak görme eğilimindedirler (Çakınberk ve Demirel, 2010: 106). Bu liderlik stilinde örgütsel amaçların gerçekleşmesi için gerekli olan kurallara uyan çalışanların ödüllendirilmesi önem arz ettiği gibi, aynı şekilde kurallara uymayanların da cezalandırılması gerekli görülmektedir (Bass ve Steidlmeier, 1999: 183).

Etkileşimli liderliğin istisnalarla yönetim (aktif), koşullu ödüllendirme, Laissez-Faire ve istisnalarla yönetim (pasif) olmak üzere dört alt boyutu bulunmaktadır.

Koşullu ödüllendirme: Lider örgütsel amaçları gerçekleştirmek isterken çalışan da kazanç düzeyini yükseltmek ister. Karşılıklı bir nevi takas olan koşullu ödüllendirme bu boyutta devre girmektedir. Örgütsel amaçlarda başarılı olundukça lider ilgili çalışanı ödüllendirmektedir. Durumun tersi yaşandıkça da çalışan cezalandırılabilir (Bass ve Avolio, 1993).

Istisnalarla aktif yönetim: Etkileşimli liderliğin bu alt boyutunda lider, genel olarak işleyişte sorun çıkmamasını arzu etmektedir. Bundan dolayı gerektiğinde işleyişe müdahale etmesini, ilgili taraflara uyarıda bulunmasını ve problemler çıkmadan engel olmaya çalışmasını ifade etmektedir (Acar, 2013: 8).

İstisnalarla pasif yönetim: Bu boyutta lider sorunlara müdahale etmez ve çalışanları serbest bırakır. Çalışanların sorun çözme becerilerinin gelişmesi ve bu durumu yönetmeyi öğrenmeleri için firsat sunmaktadır. Çözüm ve önerileri çalışanlardan bekleyen bir anlayış hâkimdir (Serinkan, 2002: 75).

Laissez-Faire: $\mathrm{Bu}$ boyut, istisnalarla pasif yönetim boyutunun en uç halidir. Lider, çalışanları tamamen serbest bırakmakta ve yönetimin bütün aşamalarında pasif kalmaktadır. Lider karar almakta ve aktif olmakta çekimser davranmaktadır. İhtiyaç duyulan anlarda lidere ulaşamamayı ifade etmektedir (Bass ve Avolio, 1993).

\section{Yöntem}

\section{Evren ve Örneklem}

Araştırmanın evreni Türkiye'de eğitim veren üniversitelerdeki 114 adet sağlık hizmetleri meslek yüksekokulunda müdür, müdür yardımcısı ve bölüm başkanı olarak görev yapan 570 akademisyenden oluşmaktadır. Araştırmada kullanılan veri toplama aracı, on-line anket olarak evrenin tamamına elektronik posta yoluyla iletilmiş, 87 akademisyen anketi doldurarak geri dönüş 
yapmıştır. Bu bağlamda araştırmanın çalışma grubunu, 2019-2020 akademik yılı bahar döneminde Türkiye genelindeki üniversitelerin sağlık hizmetleri meslek yüksekokullarında görev yapan 87 akademisyen oluşturmuştur. Çalışma grubunda yer alan yöneticilerin demografik özelliklerine göre frekans dağılımları Tablo 1'deki gibidir.

Tablo 1: Çalışma Grubuna Ait Frekans ve Yüzde Değerleri

\begin{tabular}{|c|c|c|}
\hline Cinsiyet & Frekans & Yüzde (\%) \\
\hline Erkek & 49 & 56,3 \\
\hline Kadın & 38 & 43,7 \\
\hline Toplam & 87 & 100,0 \\
\hline Yaş & Frekans & Yüzde (\%) \\
\hline 21-30 Yaş & 6 & 6,9 \\
\hline 31-40 Yaş & 41 & 47,1 \\
\hline 41-50 Yaş & 27 & 31,0 \\
\hline 51 Yaş ve Üzeri & 13 & 14,9 \\
\hline Toplam & 87 & 100,0 \\
\hline Medeni Durumu & Frekans & Yüzde (\%) \\
\hline Evli & 62 & 71,3 \\
\hline Bekâr & 25 & 28,7 \\
\hline Toplam & 87 & 100,0 \\
\hline Mesleki Kıdem & Frekans & Yüzde (\%) \\
\hline $1-10$ Y1l & 38 & 43,7 \\
\hline $11-20 Y_{11}$ & 28 & 32,2 \\
\hline 21 Y1l ve Üzeri & 21 & 24,1 \\
\hline Toplam & 87 & 100,0 \\
\hline Akademik Unvan & Frekans & Yüzde (\%) \\
\hline Profesör & 7 & 8,0 \\
\hline Doçent & 16 & 18,4 \\
\hline Dr. Öğretim Üyesi & 30 & 34,5 \\
\hline Öğretim Görevlisi & 34 & 39,1 \\
\hline Toplam & 87 & 100,0 \\
\hline İdari Görev & Frekans & Yüzde (\%) \\
\hline Müdür & 24 & 27,6 \\
\hline Müdür Yrd. & 31 & 35,6 \\
\hline Bölüm Başkanı & 32 & 36,8 \\
\hline Toplam & 87 & 100,0 \\
\hline
\end{tabular}

\section{Veri Toplama Araçları}

Araştırmada kullanılan anket üç bölümden oluşmaktadır. Birinci bölümde araştırmacılar tarafindan oluşturulan altı adet kapalı uçlu demografik soru bulunmaktadır. İkinci bölümde sağlık hizmetleri meslek yüksekokulu yöneticilerinin genel liderlik algılarını ölçmeye yönelik olarak Üstün (2014) tarafindan oluşturulmuş olan üç cevap kategorili 11 adet soru bulunmaktadır. Veri toplama aracının üçüncü bölümünü ise Şirin ve Yetim (2009) tarafindan Türkçeye uyarlanan Çok 
Faktörlü Liderlik Ölçeği oluşturmaktadır. Çok Faktörlü Liderlik Ölçeği 45 maddeden ve üç boyuttan oluşan 5'li Likert tipinde bir ölçektir. Ölçeğin maddeleri "Hiçbir zaman=1", "Arada Bir=2", "Bazen=3", "Oldukça Sik=4" ve "Her Zaman=5" biçiminde derecelendirilmiştir. Ölçekteki söz konusu üç boyut "Dönüşümcü Liderlik", "Etkileşimli Liderlik" ve "Liderlik Davranışı" şeklinde adlandırılmıştır. Her bir boyut, bünyesinde alt boyutları barındırmaktadır. Çok Faktörlü Liderlik Ölçeğinin içerdiği boyutlar, alt boyutlar ve madde sayılarına ilişkin bilgilerle birlikte ölçeğin alt boyutlarına ilişkin bu çalışma kapsamında elde edilen Cronbach $\alpha$ güvenirlik katsayıları Tablo 2'de verilmiştir.

Tablo 2: Cok Faktörlü Liderlik Ölçeği Alt Boyutları

\begin{tabular}{lllr}
\hline Boyutlar & \multicolumn{1}{c}{ Alt Boyutlar } & Maddeler & Cronbach $\boldsymbol{\alpha}$ \\
\hline \multirow{2}{*}{ Dönüşümcü } & İdealleştirilmiş Etki (Davranış) & $6,14,23,24$ & 0,730 \\
Liderlik & İdealleştirilmiş Etki (Atfedilen) & $10,18,21,25$ & 0,670 \\
& Telkinle Güdüleme & $9,13,26,36$ & 0,667 \\
& Entelektüel Uyarım & $2,8,30,32$ & 0,795 \\
& Bireysel Destek & $15,19,29,31$ & 0,650 \\
Etkileşimli & Koşullu Ödül & $1,11,16,35$ & 0,614 \\
Liderlik & İstisnalarla Yönetim (Aktif) & $4,22,24,27$ & 0,693 \\
& İstisnalarla Yönetim (Pasif) & $3,12,17,20$ & 0,771 \\
Liderlik & Laissez-Faire & $5,7,28,33$ & 0,614 \\
Davranışı & Ekstra Çaba & $39,42,44$ & 0,734 \\
& Etkililik & $37,40,43,45$ & 0,691 \\
& Memnuniyet & 38,41 & 0,669 \\
\hline
\end{tabular}

Cronbach $\alpha$ katsayısı literatürde yaygın kabul görmüş olan bir kritere göre aşağıdaki şekilde değerlendirilmektedir (Kartal ve Bardakçı, 2019: 88):

$0,00 \leq \alpha<0,40$ ise ölçek güvenilir değildir.

$0,40 \leq \alpha<0,60$ ise ölçek düşük güvenirliktedir.

$0,60 \leq \alpha<0,80$ ise ölçek oldukça güvenilirdir.

$0,80 \leq \alpha<1,00$ ise ölçek yüksek derecede güvenilirdir.

Tablo 2'de verilen Çok Faktörlü Liderlik Ölçeği alt boyutlarına ait Cronbach $\alpha$ katsayıları incelendiğinde ölçek alt boyutlarından elde edilen ortalama puanların oldukça güvenilir olduğu söylenebilir.

\section{Verilerin Toplanması}

Araştırmada kullanılacak anketin uygunluğu için Artvin Çoruh Üniversitesi Bilimsel Araştırma ve Yayın Etiği Kurulu'nun 18/02/2020 tarihli, 2020/2 no'lu oturumunda E.2696 evrak sayılı etik kurulu onayı alınmış ve anket, gönüllü olarak çalışmaya katılan ve sağlık meslek yüksekokulu yöneticiliği yapan akademisyenlere çevrimiçi olarak uygulanmıştır. Araştırmada elde edilen veriler SPSS programında kodlanmış, Çok Faktörlü Liderlik Ölçeği alt boyutlarına ait ortalama puanlar, ilgili boyutun içerdiği maddelere verilen cevapların ortalaması alınarak hesaplanmıştır.

\section{İstatistiksel Yöntem}

Sağlık meslek yüksekokulu yöneticilerinin kendileri hakkındaki genel liderlik algılarını belirlemeye yönelik yöneltilen ifadelere verdikleri cevapların dağılımı frekans tabloları ve betimleyici istatistikler kullanılarak incelenmiştir. Çok Faktörlü Liderlik Ölçeği alt boyut ortalama puanlarının normal dağılıp dağılmadığının tespit edilmesi için Kolmogorov-Smirnov testi yapılmıştır. Test sonucunda Çok Faktörlü Liderlik Ölçeği alt boyut ortalama puanlarının normal dağılım göstermediği görülmüş, örneklem büyüklüğü de dikkate alınarak verilerin analizinde nonparametrik istatistiksel yöntemlerin kullanılmasının uygun olacağ bağlamda verilerin analizinde Mann-Whitney U ve Kruskal-Wallis testleri kullanılmıştır. Kruskal- 
Wallis testine göre anlamlı farklılık tespit edilen değişkenlerin ikili karşılaştırmaları için yapılan Mann-Whitney U testlerinde önem seviyesinin belirlenmesinde Bonferroni düzeltmesi dikkate alınmıştır. Analizlerin yapılmasında IBM SPSS 25 paket programından faydalanılmıştır.

\section{Bulgular}

Bu bölümde; sağlık meslek yüksekokulu yöneticilerinin genel liderlik algılarına yönelik bulgulara ve çok faktörlü liderlik alt boyut puan ortalamalarının farklı değişkenlere göre istatistiksel farklılı̆̆

Tablo 3: Genel Liderlik Algısı İfadelerine Verilen Cevapların Frekans Dağılımı

\begin{tabular}{|c|c|c|c|}
\hline İfadeler & Evet & Kismen & Hayır \\
\hline Kendinizi lider olarak görüyor musunuz? & $\begin{array}{c}53 \\
(\% 60,9)\end{array}$ & $\begin{array}{c}30 \\
(\% 34,5)\end{array}$ & $\begin{array}{c}4 \\
(\% 4,6)\end{array}$ \\
\hline Sizce etkili bir rol model misiniz? & $\begin{array}{c}58 \\
(\% 66,7)\end{array}$ & $\begin{array}{l}26 \\
(\% 29,9)\end{array}$ & $\begin{array}{c}3 \\
(\% 3,4)\end{array}$ \\
\hline $\begin{array}{l}\text { Başarılı ve güçlü olduğunuzu düşünüyor } \\
\text { musunuz? }\end{array}$ & $\begin{array}{l}58 \\
(\% 66,7)\end{array}$ & $\begin{array}{l}27 \\
(\% 31,0)\end{array}$ & $\begin{array}{c}2 \\
(\% 2,3)\end{array}$ \\
\hline $\begin{array}{l}\text { İkna edici yönünüzün olduğunu düşünüyor } \\
\text { musunuz? }\end{array}$ & $\begin{array}{c}56 \\
(\% 64,4)\end{array}$ & $\begin{array}{c}30 \\
(\% 34,5)\end{array}$ & $\begin{array}{c}1 \\
(\% 1,1)\end{array}$ \\
\hline $\begin{array}{l}\text { Diğer çalışanlar açısından güvenilir olduğunuzu } \\
\text { düşünüyor musunuz? }\end{array}$ & $\begin{array}{c}76 \\
(\% 87,4)\end{array}$ & $\begin{array}{l}10 \\
(\% 11,5)\end{array}$ & $\begin{array}{c}1 \\
(\% 1,1)\end{array}$ \\
\hline $\begin{array}{l}\text { Sorun ya da problemlerde çözüm odakl } 1 \\
\text { misınız? }\end{array}$ & $\begin{array}{c}84 \\
(\% 96,6)\end{array}$ & $\begin{array}{c}2 \\
(\% 2,3)\end{array}$ & $\begin{array}{c}1 \\
(\% 1,1)\end{array}$ \\
\hline Yeni fikir ve önerileri destekler misiniz? & $\begin{array}{c}79 \\
(\% 90,8)\end{array}$ & $\begin{array}{c}8 \\
(\% 9,2)\end{array}$ & $\begin{array}{c}0 \\
(\% 0,0)\end{array}$ \\
\hline Diğer çalışanlarla mesafeli misiniz? & $\begin{array}{c}14 \\
(\% 16,1)\end{array}$ & $\begin{array}{c}54 \\
(\% 62,1)\end{array}$ & $\begin{array}{c}19 \\
(\% 21,8)\end{array}$ \\
\hline Eleştirilere açık mısınız? & $\begin{array}{c}48 \\
(\% 55,2)\end{array}$ & $\begin{array}{c}38 \\
(\% 43,7)\end{array}$ & $\begin{array}{c}1 \\
(\% 1,1)\end{array}$ \\
\hline İletişim düzeyinizi yüksek buluyor musunuz? & $\begin{array}{c}60 \\
(\% 69,0)\end{array}$ & $\begin{array}{l}27 \\
(\% 31,0)\end{array}$ & $\begin{array}{c}0 \\
(\% 0,0)\end{array}$ \\
\hline Değişimden zevk alır mısınız? & $\begin{array}{c}52 \\
(\% 59,8)\end{array}$ & $\begin{array}{c}33 \\
(\% 37,9)\end{array}$ & $\begin{array}{c}2 \\
(\% 2,3)\end{array}$ \\
\hline
\end{tabular}

Tablo 3'teki bulgulara göre sağlık meslek yüksekokulu yöneticilerinin \%60,9'u kendisini lider olarak gördügünü ifade ederken \%34,5'i kendisini kısmen bir lider olarak tanımladığını ifade etmektedir. Yöneticilerin \%66,7'si etkili bir rol model olduğunu, aynı zamanda başarılı ve güçlü olduğunu belirtirken, \%64,4’ü ikna edici yönünün olduğunu düşünmektedir. Yöneticilerin \%87,4 gibi büyük bir çoğunluğu kendisinin diğer çalışanlar için güvenilir birisi olduğunu belirtirken daha büyük bir çoğunluğu $(\% 96,6)$ çözüm odaklı biri olduğunu ifade etmektedir. Yeni fikir ve önerileri desteklediğini ifade eden yöneticilerin oranı \%90,8 olarak, diğer çalışanlarla mesafeli olan yöneticilerin oranı \%16,1 olarak, kısmen mesafeli olan yöneticilerin oranı ise $\% 62,1$ olarak tespit edilmiştir. Yine yöneticilerin \%,55,2'si eleştiriye açık olduğunu ifade ederken, \%43,7'si ise belli bir sınır dâhilinde eleştiriye kısmen açık olduğunu belirtmektedir. Son olarak yöneticilerin büyük çoğunluğu $(\% 69,0)$ kendi iletişim düzeyini yüksek bulurken yarısından fazlası ise $(\% 59,8)$ değişimden zevk aldığını ifade etmektedir. 
Tablo 4: Çok Faktörlü Liderlik Alt Boyutlarına İlişkin Betimleyici İstatistikler

\begin{tabular}{llcccc}
\hline Boyutlar & \multicolumn{1}{c}{ Alt Boyutlar } & Min & Max & Ort. & ss. \\
\hline & İdealleştirilmiş Etki (Davranış) & 2,50 & 5,00 & 3,93 & 0,61 \\
Dönüşümcü & İdealleştirilmiş̧ Etki (Atfedilen) & 2,25 & 5,00 & 4,01 & 0,69 \\
Liderlik & Telkinle Güdüleme & 2,25 & 5,00 & 3,97 & 0,67 \\
& Entelektüel Uyarım & 2,00 & 5,00 & 3,97 & 0,63 \\
& Bireysel Destek & 2,50 & 5,00 & 4,16 & 0,62 \\
\hline \multirow{2}{*}{ Etkileşimli } & Koşullu Ödül & 2,50 & 5,00 & 4,12 & 0,59 \\
Liderlik & İstisnalarla Yönetim (Aktif) & 1,50 & 4,75 & 2,92 & 0,74 \\
& İstisnalarla Yönetim (Pasif) & 1,00 & 4,25 & 2,12 & 0,64 \\
& Laissez-Faire & 1,00 & 3,25 & 1,66 & 0,59 \\
\multirow{2}{*}{ Liderlik } & Ekstra Çaba & 2,00 & 5,00 & 3,76 & 0,85 \\
Davranışı & Etkililik & 2,00 & 5,00 & 4,06 & 0,69 \\
& Memnuniyet & 2,00 & 5,00 & 3,89 & 0,80 \\
\hline
\end{tabular}

5'li Likert tipinde bir ölçekten alınan ortalama puanlara göre ölçülen özelliğe ilişkin tepki düzeyleri 1,00-1,50 aralığ1 "çok düşük"; 1,51-2,50 aralığ1 "düşük"; 2,51-3,50 aralığ1 "orta"; 3,514,50 aralığ1 "yüksek" ve 4,51-5,00 aralığ1 "çok yüksek" şeklinde yorumlanabilir (Kartal ve Bardakç1, 2019:97). Buna göre sağlık meslek yüksekokulu yöneticilerinin Laissez-Faire ve pasif istisnalarla yönetim alt boyut ortalama puanlarının düşük düzeyde, aktif istisnalarla yönetim alt boyut ortalama puanlarının orta düzeyde, diğer tüm alt boyut ortalama puanlarının ise yüksek düzeyde olduğu söylenebilir (Tablo 4).

Tablo 5: Cinsiyete Göre Yöneticilerin Çoklu Liderlik Alt Boyut Puanlarına İlişkin Mann-Whitney

\begin{tabular}{|c|c|c|c|c|c|c|}
\hline \multicolumn{7}{|c|}{ U Testi Sonuçları } \\
\hline Boyutlar & Alt Boyutlar & Cinsiyet & Medyan & $\mathbf{U}$ & $\mathbf{z}$ & $\mathbf{p}$ \\
\hline \multirow{5}{*}{$\begin{array}{l}\text { Dönüşümcü } \\
\text { Liderlik }\end{array}$} & $\begin{array}{l}\text { İdealleştirilmiş Etki } \\
\text { (Davranış) }\end{array}$ & $\begin{array}{l}\text { Kadın } \\
\text { Erkek }\end{array}$ & $\begin{array}{l}4,00 \\
3,75\end{array}$ & 823,50 & 0,927 & 0,354 \\
\hline & $\begin{array}{l}\text { İdealleştirilmiş Etki } \\
\text { (Atfedilen) }\end{array}$ & $\begin{array}{l}\text { Kadın } \\
\text { Erkek }\end{array}$ & $\begin{array}{l}4,25 \\
4,00\end{array}$ & 888,00 & 0,371 & 0,711 \\
\hline & Telkinle Güdüleme & $\begin{array}{l}\text { Kadın } \\
\text { Erkek }\end{array}$ & $\begin{array}{l}4,00 \\
4,00\end{array}$ & 885,50 & 0,393 & 0,694 \\
\hline & Entelektüel Uyarım & $\begin{array}{l}\text { Kadın } \\
\text { Erkek }\end{array}$ & $\begin{array}{l}4,25 \\
4,00 \\
\end{array}$ & 734,00 & 1,707 & 0,088 \\
\hline & Bireysel Destek & $\begin{array}{l}\text { Kadın } \\
\text { Erkek }\end{array}$ & $\begin{array}{l}4,50 \\
4,00\end{array}$ & 717,00 & 1,848 & 0,065 \\
\hline \multirow{4}{*}{$\begin{array}{l}\text { Etkileşimli } \\
\text { Liderlik }\end{array}$} & Koşullu Ödül & $\begin{array}{l}\text { Kadın } \\
\text { Erkek }\end{array}$ & $\begin{array}{l}4,25 \\
4,00\end{array}$ & 802,50 & 1,109 & 0,267 \\
\hline & $\begin{array}{l}\text { İstisnalarla Yönetim } \\
\text { (Aktif) }\end{array}$ & $\begin{array}{l}\text { Kadın } \\
\text { Erkek }\end{array}$ & $\begin{array}{l}2,75 \\
2,75\end{array}$ & 900,00 & 0,267 & 0,789 \\
\hline & $\begin{array}{l}\text { İstisnalarla Yönetim } \\
\text { (Pasif) }\end{array}$ & $\begin{array}{l}\text { Kadın } \\
\text { Erkek }\end{array}$ & $\begin{array}{l}2,00 \\
2,25\end{array}$ & 643,00 & 2,482 & $\mathbf{0 , 0 1 3}$ \\
\hline & Laissez-Faire & $\begin{array}{l}\text { Kadın } \\
\text { Erkek }\end{array}$ & $\begin{array}{l}1,50 \\
1,63\end{array}$ & 786,00 & 1,270 & 0,204 \\
\hline & Ekstra Çaba & $\begin{array}{l}\text { Kadın } \\
\text { Erkek }\end{array}$ & $\begin{array}{l}4,00 \\
4,00 \\
\end{array}$ & 913,50 & 0,152 & 0,879 \\
\hline Liderlik Davranışı & Etkililik & $\begin{array}{l}\text { Kadın } \\
\text { Erkek }\end{array}$ & $\begin{array}{l}4,25 \\
4,25 \\
\end{array}$ & 890,50 & 0,350 & 0,726 \\
\hline & Memnuniyet & $\begin{array}{l}\text { Kadın } \\
\text { Erkek }\end{array}$ & $\begin{array}{l}4,00 \\
4,00\end{array}$ & 809,50 & 1,073 & 0,283 \\
\hline
\end{tabular}

Tablo 5'teki Mann-Whitney U testi sonuçlarına göre, sağl1k meslek yüksekokulu yöneticilerinin pasif istisnalarla yönetim alt boyut ortalama puanları cinsiyete göre anlamlı bir farklılık göstermektedir $(\mathrm{p}<0,05)$. Bu durumla birlikte cinsiyet gruplarına ait medyan değerleri de 
dikkate alındığında erkek yöneticilerin pasif istisnalarla yönetim alt boyut ortalama puanlarının kadın yöneticilere göre anlamlı derecede yüksek olduğu görülmektedir. Diğer bütün çoklu liderlik alt boyut ortalama puanlarının ise cinsiyet değişkenine göre anlamlı bir farklılık göstermediği görülmüştür $(\mathrm{p}>0,05)$.

Tablo 6: Medeni Duruma Göre Yöneticilerin Çoklu Liderlik Alt Boyut Puanlarına İlişkin Mann-

Whitney U Testi Sonuçları

\begin{tabular}{|c|c|c|c|c|c|c|}
\hline Boyutlar & Alt Boyutlar & $\begin{array}{l}\text { Medeni } \\
\text { Durum }\end{array}$ & Medyan & $\mathbf{U}$ & $\mathbf{z}$ & $\mathbf{p}$ \\
\hline \multirow{10}{*}{ Dönüşümcü Liderlik } & \multirow{2}{*}{$\begin{array}{l}\text { İdealleştirilmiş Etki } \\
\text { (Davranış) }\end{array}$} & Evli & 4,00 & \multirow[b]{2}{*}{688,00} & \multirow[b]{2}{*}{0,822} & \multirow[b]{2}{*}{0,411} \\
\hline & & Bekâr & 3,75 & & & \\
\hline & \multirow{2}{*}{$\begin{array}{l}\text { İdealleştirilmiş Etki } \\
\text { (Atfedilen) }\end{array}$} & Evli & 4,25 & \multirow[b]{2}{*}{712,00} & \multirow{2}{*}{0,596} & \multirow{2}{*}{0,551} \\
\hline & & Bekâr & 4,25 & & & \\
\hline & \multirow{2}{*}{ Telkinle Güdüleme } & Evli & 4,00 & \multirow{2}{*}{682,50} & \multirow{2}{*}{0,875} & \multirow{2}{*}{0,381} \\
\hline & & Bekâr & 3,75 & & & \\
\hline & \multirow{2}{*}{ Entelektüel Uyarım } & Evli & 4,00 & \multirow{2}{*}{543,00} & \multirow{2}{*}{2,203} & \multirow{2}{*}{$\mathbf{0 , 0 2 8}$} \\
\hline & & Bekâr & 3,75 & & & \\
\hline & \multirow{2}{*}{ Bireysel Destek } & Evli & 4,25 & \multirow{2}{*}{601,00} & \multirow{2}{*}{1,647} & \multirow{2}{*}{0,100} \\
\hline & & Bekâr & 4,00 & & & \\
\hline \multirow{8}{*}{ Etkileşimli Liderlik } & \multirow{2}{*}{ Koşullu Ödül } & Evli & 4,25 & \multirow{2}{*}{560,50} & \multirow{2}{*}{2,029} & \multirow{2}{*}{0,042} \\
\hline & & Bekâr & 4,00 & & & \\
\hline & \multirow{2}{*}{$\begin{array}{l}\text { İstisnalarla Yönetim } \\
\text { (Aktif) }\end{array}$} & Evli & 2,75 & \multirow{2}{*}{766,00} & \multirow{2}{*}{0,085} & \multirow{2}{*}{0,932} \\
\hline & & Bekâr & 2,75 & & & \\
\hline & \multirow{2}{*}{$\begin{array}{l}\text { İstisnalarla Yönetim } \\
\text { (Pasif) }\end{array}$} & Evli & 2,00 & \multirow{2}{*}{752,00} & \multirow{2}{*}{0,217} & 0828 \\
\hline & & Bekâr & 2,00 & & & 0,828 \\
\hline & & Evli & 1,50 & & & 0855 \\
\hline & Laissez-Faire & Bekâr & 1,50 & 156,00 & 0,182 & 0,855 \\
\hline & & Evli & 4,00 & & 0661 & \\
\hline & Ekstra Çaba & Bekâr & 4,00 & 105,50 & 0,661 & 0,509 \\
\hline L iderlik Davranıs & Ftkililik & Evli & 4,25 & 71850 & 0.535 & 0503 \\
\hline Liderı1K Davranışı & Etk1l1l1k & Bekâr & 4,25 & 118,50 & 0,535 & 0,593 \\
\hline & Memnunivet & Evli & 4,00 & 69150 & 0808 & 0.419 \\
\hline & viemimumyet & Bekâr & 4,00 & 091,50 & 0,000 & 0,419 \\
\hline
\end{tabular}

Tablo 6'daki bulgulara göre, sağllk meslek yüksekokulu yöneticilerinin dönüşümcü liderlik entelektüel uyarım alt boyutu ve etkileşimli liderlik koşullu ödül alt boyutu ortalama puanları medeni durumlarına göre anlamlı bir farklılık göstermektedir $(p<0,05)$. Evli ve bekâr yöneticilerin medyan değerleri göz önüne alındığında evli yöneticilerin entelektüel uyarım ve koşullu ödül alt boyut ortalama puanlarının bekâr yöneticilere göre anlamlı derecede daha yüksek olduğu söylenebilir. Diğer çoklu liderlik alt boyut ortalama puanları ise yöneticilerin medeni durumlarına göre anlamlı bir farkl1lık arz etmemektedir $(\mathrm{p}>0,05)$.

Sağlık meslek yüksekokulu yöneticilerinin çoklu liderlik alt boyut ortalama puanlarının yöneticilerin yaşına göre anlamlı bir farklılık arz edip etmediğini Kruskal-Wallis Testi ile incelenmiş, yapılan test sonucunda sadece Tablo 7'de görüldüğü gibi ekstra çaba alt boyutunda anlamlı bir farklılık görülmüştür. Diğer çoklu liderlik alt boyut ortalama puanları ise yöneticilerin yaşına göre anlamlı bir farklılık göstermemiştir. 
Tablo 7: Yaşa Göre Yöneticilerin Çoklu Liderlik Alt Boyut Puanlarına İlişkin Kruskal-Wallis Testi Sonuçları

\begin{tabular}{|c|c|c|c|c|c|c|c|c|c|c|}
\hline \multirow{2}{*}{ Boyut } & \multirow{2}{*}{$\begin{array}{c}\text { Alt } \\
\text { Boyut }\end{array}$} & \multirow{2}{*}{ Yaş } & \multirow{2}{*}{$\mathbf{n}$} & \multirow{2}{*}{ Medyan } & \multirow{2}{*}{ sd } & \multirow{2}{*}{$\chi^{2}$} & \multirow{2}{*}{$\mathbf{p}$} & \multicolumn{3}{|c|}{ Mann-Whitney U Testi } \\
\hline & & & & & & & & $\mathbf{U}$ & $\mathbf{p}$ & Gruplar \\
\hline \multirow{4}{*}{$\begin{array}{c}\text { Liderlik } \\
\text { Davranışı }\end{array}$} & \multirow{4}{*}{$\begin{array}{c}\text { Ekstra } \\
\text { Çaba }\end{array}$} & 21-30 Yaş & 6 & 3,17 & \multirow{4}{*}{3} & \multirow{4}{*}{14,876} & \multirow{4}{*}{0,002} & 86,00 & 0,000 & $2-4 *$ \\
\hline & & 31-40 Yaş & 41 & 3,33 & & & & - & - & - \\
\hline & & $41-50$ Yaş & 27 & 4,00 & & & & - & - & - \\
\hline & & $\begin{array}{l}51 \text { Yaş ve } \\
\text { Üzeri }\end{array}$ & 13 & 4,50 & & & & - & - & - \\
\hline
\end{tabular}

Tablo 7'deki sonuçlar doğrultusunda yaş gruplarına ait ekstra çaba boyutu medyan değerleri dikkate alındığında sağlık meslek yüksekokulu yöneticilerinin yaşları arttıkça ekstra çabalarının da arttığı görülmektedir. Tablo 7'de aynı zamanda yaş gruplarına ait Mann-Whitney U ikili karşılaştırma testlerinin sonucunda farklılık tespit edilen gruplara da yer verilmiştir. Bonferroni düzeltmesi dikkate alınarak toplam önem seviyesi yapılan ikili karşılaştırma sayısına bölünerek testlerin önem seviyesi $0,05 / 6=0,008$ olarak belirlenmiştir. Buna göre 51 yaş ve üzerindeki yöneticilerin ekstra çaba ortalama puanlarının 31-40 yaş aralığındaki yöneticilere göre yüksek düzeyde anlamlı anlamlı olduğu saptanmıştır $(U=86,00 ; p<0,008)$.

Sağlık meslek yüksekokulu yöneticilerinin çoklu liderlik alt boyut ortalama puanlarının meslekteki k1demlerine göre anlamlı bir farklılık arz edip etmediği yine Kruskal-Wallis Testi ile incelenmiștir. Test sonucunda sadece anlamlı farklılık tespit edilen alt boyutlara ait sonuçlar Tablo 8 'de verilmiştir.

Tablo 8: Mesleki Kıdeme Göre Yöneticilerin Çoklu Liderlik Alt Boyut Puanlarına İlişkin KruskalWallis Testi Sonuçları

\begin{tabular}{|c|c|c|c|c|c|c|c|c|c|c|}
\hline \multirow{2}{*}{ Boyut } & \multirow{2}{*}{ Alt Boyut } & \multirow{2}{*}{ Kidem } & \multirow{2}{*}{$\mathbf{n}$} & \multirow{2}{*}{ Medyan } & \multirow{2}{*}{ sd } & \multirow{2}{*}{$\chi^{2}$} & \multirow{2}{*}{$\mathbf{p}$} & \multicolumn{3}{|c|}{ Mann-Whitney U Testi } \\
\hline & & & & & & & & $\overline{\mathbf{U}}$ & $\mathbf{p}$ & Gruplar \\
\hline \multirow{9}{*}{$\begin{array}{l}\text { Dönüşümcü } \\
\text { Liderlik }\end{array}$} & \multirow{3}{*}{$\begin{array}{l}\text { İdeal Etki } \\
\text { (Atfedilen) }\end{array}$} & $1-10$ Y11 & 38 & 4,00 & \multirow{3}{*}{2} & \multirow{3}{*}{12,196} & \multirow{3}{*}{0,002} & 277,00 & 0,001 & $1-2^{*}$ \\
\hline & & $11-20 Y_{11}$ & 28 & 4,38 & & & & - & - & - \\
\hline & & $\begin{array}{l}21 \text { Y1l ve } \\
\text { Üzeri }\end{array}$ & 21 & 4,25 & & & & - & - & - \\
\hline & \multirow{3}{*}{$\begin{array}{l}\text { ü Telkinle } \\
\text { Güdüleme }\end{array}$} & $1-10 \mathrm{Y}_{11}$ & 38 & 3,75 & \multirow{3}{*}{2} & \multirow{3}{*}{8,775} & \multirow{3}{*}{0,012} & 315,00 & 0,004 & $1-2 *$ \\
\hline & & $11-20 Y_{11}$ & 28 & 4,13 & & & & - & - & - \\
\hline & & $\begin{array}{l}21 \text { Y1l ve } \\
\text { Üzeri }\end{array}$ & 21 & 4,25 & & & & - & - & - \\
\hline & \multirow{3}{*}{$\begin{array}{l}\text { Entelektüel } \\
\text { Uyarım }\end{array}$} & 1-10 Y1l & 38 & 3,88 & \multirow{3}{*}{2} & \multirow{3}{*}{13,615} & \multirow{3}{*}{0,001} & 311,50 & 0,004 & $1-2^{*}$ \\
\hline & & \multirow{2}{*}{$\begin{array}{l}11-20 \mathrm{Y}_{1} 1 \\
21 \mathrm{Y}_{1} 1 \mathrm{ve} \\
\text { Üzeri }\end{array}$} & 28 & 4,25 & & & & 200,00 & 0,001 & $1-3^{*}$ \\
\hline & & & 21 & 4,25 & & & & - & - & - \\
\hline \multirow{9}{*}{$\begin{array}{l}\text { Liderlik } \\
\text { Davranış1 }\end{array}$} & \multirow{3}{*}{ Ekstra Çaba } & 1-10 Y1l & 38 & 3,33 & \multirow{3}{*}{2} & \multirow{3}{*}{14,857} & \multirow{3}{*}{0,001} & 167,50 & 0,000 & $1-3^{*}$ \\
\hline & & $11-20 Y_{11}$ & 28 & 4,00 & & & & - & - & - \\
\hline & & $\begin{array}{l}21 \text { Y1l ve } \\
\text { Üzeri }\end{array}$ & 21 & 4,33 & & & & - & - & - \\
\hline & \multirow{3}{*}{ Etkililik } & 1-10 Y1l & 38 & 4,00 & \multirow{3}{*}{2} & \multirow{3}{*}{9,029} & \multirow{3}{*}{0,011} & 230,50 & 0,007 & $1-3^{*}$ \\
\hline & & $11-20 Y_{11}$ & 28 & 4,25 & & & & - & - & - \\
\hline & & $\begin{array}{l}21 \text { Yll ve } \\
\text { Üzeri }\end{array}$ & 21 & 4,50 & & & & - & - & - \\
\hline & \multirow{3}{*}{ Memnuniyet } & 1-10 Y1l & 38 & 4,00 & \multirow{3}{*}{2} & & & 172,50 & 0,000 & $1-3 *$ \\
\hline & & $11-20 Y_{11}$ & 28 & 4,00 & & 13.063 & 0,001 & - & - & - \\
\hline & & $\begin{array}{l}21 \text { Yll ve } \\
\text { Üzeri }\end{array}$ & 21 & 4,50 & & & & - & - & - \\
\hline
\end{tabular}


Tablo 8'deki bulgulara göre dönüşümcü liderlik alt boyutlarından olan atfedilen ideal etki, telkinle güdüleme ve entelektüel uyarım alt boyut puanları ile birlikte liderlik davranışı alt boyutları olan ekstra çaba, etkililik ve memnuniyet alt boyut puanları yöneticilerin mesleki k1demine göre anlamlı bir farklılık göstermektedir $(\mathrm{p}<0,05)$. Tablo 8 'de yer alan kıdem gruplarına ait Mann-Whitney U ikili karşılaştırma testlerinin sonucunun değerlendirilmesinde Bonferroni düzeltmesi dikkate alınarak testlerin önem seviyesi $0,05 / 3=0,017$ olarak belirlenmiştir. Buna göre öncelikle mesleki kıdemi 11-20 yıl arası olan yöneticilerin atfedilen ideal etki, telkinli güdüleme ve entelektüel uyarım ortalama puanlarının kıdemi 1-10 yıl arasında olan yöneticilere göre daha yüksek olduğu, ayrıca mesleki kıdemi 21 yıl ve üzeri olan yöneticilerin entelektüel uyarım ortalama puanlarının meslekteki kıdemi 1-10 yıl arasında olan yöneticilere göre daha yüksek olduğu belirlenmiştir $(\mathrm{p}<0,017)$. Liderlik davranışı boyutunun alt boyutları olan ekstra çaba, etkililik ve memnuniyet ortalama puanları dikkate alındığında ise her üç boyutta da meslekteki kıdemi 21 yıl ve üzeri olan yöneticilerin ortalamasının meslekteki kıdemi 1-10 yıl arasında olan yöneticilere göre anlamlı derecede daha yüksek olduğu belirlenmiştir $(\mathrm{p}<0,017)$.

Sağlik meslek yüksekokulu yöneticilerinin çoklu liderlik alt boyut ortalama puanlarının yöneticilerin akademik unvanına göre anlamlı bir farklılık gösterip göstermediği yine KruskalWallis Testi ile incelenmiştir. Test sonucunda anlamlı farklılık tespit edilen alt boyutlarla ilgili sonuçlar Tablo 9'da verildiği gibidir.

Tablo 9: Akademik Unvana Göre Yöneticilerin Çoklu Liderlik Alt Boyut Puanlarına İlişkin Kruskal-Wallis Testi Sonuçları

\begin{tabular}{|c|c|c|c|c|c|c|c|c|c|c|}
\hline \multirow{2}{*}{ Boyut } & \multirow{2}{*}{$\begin{array}{c}\text { Alt } \\
\text { Boyut }\end{array}$} & \multirow{2}{*}{$\begin{array}{l}\text { Akademik } \\
\text { Unvan }\end{array}$} & \multirow{2}{*}{$\mathbf{n}$} & \multirow{2}{*}{ Medyan } & \multirow{2}{*}{ sd } & \multirow{2}{*}{$\chi^{2}$} & \multirow{2}{*}{$\mathbf{p}$} & \multicolumn{3}{|c|}{ Mann-Whitney U Testi } \\
\hline & & & & & & & & $\mathbf{U}$ & $\mathbf{p}$ & Gruplar \\
\hline \multirow{8}{*}{$\begin{array}{c}\text { Liderlik } \\
\text { Davranış1 }\end{array}$} & & Profesör & 7 & 4,50 & \multirow{4}{*}{3} & \multirow{4}{*}{8,732} & \multirow{4}{*}{0,033} & 150,50 & 0,001 & $2-4^{*}$ \\
\hline & Ekstra & Doçent & 16 & 4,17 & & & & - & - & - \\
\hline & Çaba & Dr.Öğr. Üyesi & 30 & 4,00 & & & & - & - & - \\
\hline & & Öğr. Görevlisi & 34 & 3,33 & & & & - & - & - \\
\hline & \multirow{4}{*}{ Etkililik } & Profesör & 7 & 4,75 & \multirow{4}{*}{3} & \multirow{4}{*}{9,252} & \multirow{4}{*}{0,026} & 49,50 & 0,004 & $1-4 *$ \\
\hline & & Doçent & 16 & 4,38 & & & & 162,00 & 0,002 & $2-4 *$ \\
\hline & & Dr. Öğr. Üyesi & 30 & 4,00 & & & & - & - & - \\
\hline & & Öğr. Görevlisi & 34 & 4,00 & & & & - & - & - \\
\hline
\end{tabular}

Tablo 9'daki sonuçlar doğrultusunda liderlik davranışı boyutunun alt boyutları olan ekstra çaba ve etkililik ortalama puanlarının yöneticilerin akademik unvanına göre anlamlı bir farklılık gösterdiği saptanmıştır $(\mathrm{p}<0,05)$. Gruplar arasında yapılan ikili karşıllaştırmalarda testlerin önem seviyesi Bonferroni düzeltmesi kullanılarak 0,05/6=0,008 şeklinde belirlenmiştir. Buna göre doçent unvanına sahip olan sağlık hizmetleri meslek yüksekokulu yöneticilerinin ekstra çaba ve etkililik puanlarının öğretim görevlisi unvanını taşıyan yöneticilere göre anlamlı derecede daha yüksek olduğu görülmüştür $(\mathrm{p}<0,008)$. Aynı zamanda profesör unvanına sahip olan yöneticilerin etkililik puanlarının öğretim görevlisi unvanına sahip yöneticilere göre anlamlı derecede daha yüksek olduğu da görülmüştür.

Son olarak sağlık meslek yüksekokulu yöneticilerinin çoklu liderlik alt boyut ortalama puanlarının yöneticilerin idari görevine göre anlamlı bir farklılık arz edip etmediğini yine KruskalWallis Testi kullanılarak incelenmiş ve anlamlı farklılık tespit edilen alt boyutlara ilişkin bulgulara Tablo 10'da yer verilmiştir. 
Tablo 10: İdari Göreve Göre Yöneticilerin Çoklu Liderlik Alt Boyut Puanlarına İlişkin KruskalWallis Testi Sonuçları

\begin{tabular}{|c|c|c|c|c|c|c|c|c|c|c|}
\hline \multirow{2}{*}{ Boyut } & \multirow{2}{*}{ Alt Boyut } & \multirow{2}{*}{ İdari Görev } & \multirow{2}{*}{$\mathbf{n}$} & \multirow{2}{*}{ Medyan } & \multirow{2}{*}{ sd } & \multirow{2}{*}{$\chi^{2}$} & \multirow{2}{*}{$\mathbf{p}$} & \multicolumn{3}{|c|}{ Mann-Whitney U Testi } \\
\hline & & & & & & & & $\mathbf{U}$ & $\mathbf{p}$ & Gruplar \\
\hline \multirow{6}{*}{$\begin{array}{l}\text { Dönüşümc } \\
\text { ü Liderlik }\end{array}$} & \multirow{3}{*}{$\begin{array}{l}\text { İdeal Etki } \\
\text { (Atfedilen) }\end{array}$} & Müdür & 24 & 4,50 & \multirow{3}{*}{2} & \multirow{3}{*}{13,824} & \multirow{3}{*}{0,001} & 175,50 & 0,001 & $1-2 *$ \\
\hline & & Müdür Yrd. & 31 & 4,00 & & & & 194,50 & 0,002 & $1-3 *$ \\
\hline & & $\begin{array}{l}\text { Bölüm } \\
\text { Başkanı }\end{array}$ & 32 & 4,13 & & & & - & - & - \\
\hline & \multirow{3}{*}{$\begin{array}{l}\text { Telkinle } \\
\text { Güdüleme }\end{array}$} & Müdür & 24 & 4,50 & \multirow{3}{*}{2} & \multirow{3}{*}{12,504} & \multirow{3}{*}{0,002} & 187,00 & 0,002 & $1-2^{*}$ \\
\hline & & Müdür Yrd. & 31 & 4,00 & & & & 200,00 & 0,002 & $1-3 *$ \\
\hline & & $\begin{array}{l}\text { Bölüm } \\
\text { Başkan }\end{array}$ & 32 & 4,00 & & & & - & - & - \\
\hline \multirow{3}{*}{$\begin{array}{l}\text { Etkileşimli } \\
\text { Liderlik }\end{array}$} & \multirow{3}{*}{$\begin{array}{l}\text { Laissez } \\
\text { Faire }\end{array}$} & Müdür & 24 & 1,25 & \multirow{3}{*}{2} & \multirow{3}{*}{11,162} & \multirow{3}{*}{0,004} & 186,50 & 0,001 & $1-2^{*}$ \\
\hline & & Müdür Yrd. & 31 & 1,50 & & & & 229,50 & 0,008 & $1-3 *$ \\
\hline & & $\begin{array}{l}\text { Bölüm } \\
\text { Başkan }\end{array}$ & 32 & 1,75 & & & & - & - & - \\
\hline \multirow{9}{*}{$\begin{array}{l}\text { Liderlik } \\
\text { Davranış1 }\end{array}$} & \multirow{3}{*}{ Ekstra Çaba } & Müdür & 24 & 4,33 & \multirow{3}{*}{2} & \multirow{3}{*}{8,878} & \multirow{3}{*}{0,012} & 213,00 & 0,004 & $1-3 *$ \\
\hline & & Müdür Yrd. & 31 & 4,00 & & & & - & - & - \\
\hline & & $\begin{array}{l}\text { Bölüm } \\
\text { Başkanı }\end{array}$ & 32 & 3,50 & & & & - & - & - \\
\hline & \multirow{3}{*}{ Etkililik } & Müdür & 24 & 4,75 & \multirow{3}{*}{2} & \multirow{3}{*}{15,220} & \multirow{3}{*}{0,000} & 173,50 & 0,001 & $1-2^{*}$ \\
\hline & & Müdür Yrd. & 31 & 4,00 & & & & 176,00 & 0,001 & $1-3 *$ \\
\hline & & $\begin{array}{l}\text { Bölüm } \\
\text { Başkanı }\end{array}$ & 32 & 4,00 & & & & - & - & - \\
\hline & \multirow{3}{*}{ Memnuniyet } & Müdür & 24 & 4,50 & \multirow{3}{*}{2} & & & 222,00 & 0,006 & $1-3^{*}$ \\
\hline & & Müdür Yrd. & 31 & 4,00 & & 8,260 & 0,016 & - & - & - \\
\hline & & $\begin{array}{l}\text { Bölüm } \\
\text { Başkanı }\end{array}$ & 32 & 4,00 & & & & - & - & - \\
\hline
\end{tabular}

Tablo 10'daki bulgulara göre, dönüşümcü liderlik alt boyutlarından olan atfedilen ideal etki ve telkinle güdüleme puanları ile birlikte etkileşimli liderlik alt boyutlarından olan Laissez Faire ve liderlik davranışı alt boyutları olan ekstra çaba, etkililik ve memnuniyet puanları, yöneticilerin idari görevine göre anlamlı bir farklılık göstermektedir $(p<0,05)$. Farlılık gösteren grupların tespiti için yapılan Mann-Whitney U ikili karşılaştırma testlerinde önem seviyesi Bonferroni düzeltmesi dikkate alınarak $0,05 / 3=0,017$ olarak alınmıştır. Buna göre sağlık meslek yüksekokulu müdürlerinin atfedilen ideal etki, telkinle güdüleme ve etkililik puanlarının hem müdür yardımcılarına hem de bölüm başkanlarına göre anlamlı derecede daha yüksek olduğu belirlenmiştir. Laissez Faire alt boyut puanlarında ise müdürlerin ortalama puanlarının hem müdür yardımcılarına hem de bölüm başkanlarına göre anlamlı derecede daha düşük olduğu tespit edilmiştir. Ekstra çaba ve memnuniyet alt boyut puanlarında ise sadece müdürler ile bölüm başkanları arasında farklılık belirlenmiş, müdürlerin ekstra çaba ve memnuniyet ortalama puanlarının bölüm başkanlarına göre anlamlı derecede daha yüksek olduğu saptanmıştır.

\section{Tartışma}

Sağllk Hizmetleri Meslek Yüksekokullarının yönetiminde yer alan akademisyenlerin, genel liderlik stillerini belirlemeye yönelik yapılan bu çalışmada, önemli bulgulara ulaşılmıştır. Bu kısımda çalışmada elde edilen bulgular literatürdeki benzer çalışmalarla karşılaştırılarak tartışılmıştır.

Çalışmada ilk olarak yöneticilerin genel liderlik algılarına yönelik bulgulara yer verilmiştir. Buna göre, yöneticilerin \%60,9'u kendisini lider olarak gördüğünü ifade ederken \%34,5'i kendisini kısmen bir lider olarak tanımladığını ifade etmektedir. Buna göre yöneticilerin yaklaşık \% 40 '1 kendisini tam bir lider olarak görmemektedir. Diğer bir bulguya göre çalışanlarla mesafeli olan 
yöneticilerin oranı \%16,1 olarak, kısmen mesafeli olan yöneticilerin oranı ise $\% 62,1$ olarak tespit edilmiştir. Buna göre yöneticilerin çoğunluğunun çalışanlarıyla kısmen de olsa bir mesafe içerisinde olması gerektiğini düşündüğü söylenebilir. Yine yöneticilerin $\%, 55,2$ 'si eleştiriye açık olduğunu ifade ederken, \%43,7'si ise belli bir sınır dâhilinde eleştiriye kısmen açık olduğunu belirtmektedir. Buna göre yöneticilerin yaklaşık \%45'inin sınırsız eleştiriye karşı oldukları görülmektedir.

Çalışmada elde edilen bulgulara göre dönüşümcü liderlik ve alt boyut ortalama puanlarının yüksek düzeyde olduğu görülmüştür. Literatürde bu bulguyu destekler nitelikte Yavuz (2009) ve Üstün (2014) tarafindan yapılan çalışmalarda da benzer bulgular elde edilmiştir. Genel olarak kamu kurumlarında dönüşümcü liderlik stilinin teorik olarak daha çok kabul gördüğü bilinmektedir. Dolaysıyla bu çalışmadan elde edilen bu bulgu literatürle uyuşması beklenilen bir durumdur.

Çalışmada sağlık hizmetleri meslek yüksekokulu yöneticilerinin etkileşimli liderlik ortalama puanının orta düzeyde belirlenmiş̧tir. Bu sonuç Kul ve Güçlü (2010) tarafından yapılan çalışmanın sonuçlarıyla paralellik göstermektedir. Çalışmada etkileşimli liderlik alt boyutlarından koşullu ödüllendirme ortalama puanı yüksek düzeyde, aktif istisnalarla yönetim boyutu orta düzeyde ve diğer alt boyutların ise düşük düzeyde olduğu saptanmıştır. Bu sonuçlara benzer şekilde Kul ve Güçlü (2010) çalışmalarında koşullu ödüllendirme ve aktif istisnalarla yönetim boyutu ortalama puanını yüksek düzeyde, pasif istisnalarla yönetim ortalama puanını orta düzeyde, Laissez Faire ortalama puanını ise düşük düzeyde olarak tespit ermişlerdir. Çalışmada tespit edilen etkileşimli liderlik ortalama puanının literatürdeki benzer konulu çalışmalardan elde edilen bulgulara göre daha düşük olduğu görülmüsstür. $\mathrm{Bu}$ durumun nedeni, meslek gereği akademisyenlerin daha çok bağımsız çalışmaya yatkın olması ve akademik hiyerarşinin çok keskin olmamasına bağlanabilir. Yönetim kademesindeki akademisyenlerin, kurumsal işleyişe müdahale alanının dar olması da bu durumun bir diğer önemli sebebi olarak düşünebilir.

Çalışmada genel olarak dönüşümcü liderlik stilinin etkileşimli liderlik stilinden daha çok öne çıktığ 1 görülmüştür. Bu sonuç literatürdeki çok sayıda çalışmadan elde edilen bulgularla paralellik göstermektedir. Üstün (2014), Cemaloğlu ve Okçu (2012), Buluç (2009), Kul ve Güçlü (2010) çalışmalarında benzer sonuçları elde etmişlerdir. Bu çalışmada özellikle yönetim kademesinde görev alan akademisyenlerden de bu sonucun elde edilmesi önemli bir bulgu olarak nitelendirilebilir.

Çalı̧̧mada etkileşimli liderliğin sadece pasif istisnalarla yönetim alt boyutunun erkek yöneticilerde kadın yöneticilere göre anlamlı derecede daha yüksek olduğu, diğer bütün çoklu liderlik alt boyut ortalama puanlarının ise cinsiyet değişkenine göre bir farklılık göstermediği tespit edilmiştir. Üstün (2014) çalışmasında etkileşimli liderliğin cinsiyete göre farklılık göstermediğini ancak alt boyutlarından koşul ödüllendirme boyutunda kadınların erkeklere göre daha yüksek algı düzeyine sahip olduklarını tespit etmiştir. Diğer taraftan Üstün (2014), Hemedoğlu ve Evliyaoğlu (2012), Keklik (2012) ve Arslantaş ve Pekdemir (2007) tarafindan yapılan çalışmalarda da dönüşümcü liderliğin ortalama puanları arasında bu çalışmada olduğu gibi cinsiyet değişkenine göre anlamlı bir farkl1l1k görülmemiştir. Üstün (2014) sadece dönüşümcü liderliğin alt boyutlarından olan telkinle güdüleme boyutunda kadın yöneticilerin erkek yöneticilere göre daha yüksek puana sahip olduğu sonucuna ulaşmıştır.

$\mathrm{Bu}$ çalışmada, evli ve bekâr yöneticilerin çoklu liderlik alt boyutlarına yönelik ortalama değerleri göz önüne alındığında evli yöneticilerin dönüşümcü liderliğin entelektüel uyarım ve etkileşimli liderliğin koşullu ödül alt boyut ortalama puanlarının bekâr yöneticilere göre anlamlı derecede daha yüksek olduğu görülmüş̧tür. Diğer çoklu liderlik alt boyut ortalama puanları ise yöneticilerin medeni durumlarına göre anlamlı bir farklılık göstermemiştir. Üstün (2014) ise çalışmasında bu çalışmanın aksine olarak medeni duruma göre çoklu liderlik alt boyutlarının hiç birisinde yöneticilerin medeni durumuna göre anlamlı bir farkl1lı tespit etmemiştir. 
Çalışmada elde edilen bir diğer bulguya göre ekstra çaba alt boyutunda sağlik meslek yüksekokulu yöneticilerinin yaşına göre anlamlı bir farklılık görülmüştür. $\mathrm{Bu}$ bağlamda yöneticilerin yaşları artıkça ekstra çabalarının da arttığı tespit edilmiştir. Özellikle ileri yaş grubu olarak nitelendirilebilecek olan 51 yaş ve üzerindeki yöneticilerin ekstra çaba düzeylerinin orta yaş grubu olarak nitelendirilebilecek olan 31-40 yaş aralığındaki yöneticilere göre anlamlı derecede daha yüksek olduğu saptanmıştır. Üstün (2014) çalışmasında 51 yaş ve üstü yöneticilerin telkinle güdüleme, dönüşümcü liderlik ve etkileşimli liderlik alt boyut ortalama puanlarının 41 ve 50 yaş arası yöneticilere göre daha yüksek olduğunu gözlemlemiştir. Bu çalışmada elde edilen bulgular literatürdeki çalışmalarla tam olarak örtüşmese de, genel olarak yaş artıkça liderlik davranışlarında da olumlu yönde davranışların arttı̆̆ 1 söylenebilir. Bireyin yaşı ilerledikçe tecrübesinin arttığ 1 ve karakterinin oturduğu düşüncesinden hareketle, çalışmanın bu bulgusu anlamlı ve mantıklı görülmektedir.

Çalışmanın diğer bir bulgusuna göre, dönüşümcü liderlik alt boyutlarından olan atfedilen ideal etki, telkinle güdüleme ve entelektüel uyarım alt boyut puanları ile birlikte liderlik davranışı alt boyutları olan ekstra çaba, etkililik ve memnuniyet puanları yöneticilerin mesleki kıdemine göre anlamlı bir farklılık göstermektedir. Bu bağlamda, mesleki kıdemi 11-20 yıl arası olan yöneticilerin atfedilen ideal etki, telkinle güdüleme ve entelektüel uyarım düzeylerinin k1demi 10 yıldan az olan yöneticilere göre daha yüksek olduğu ve ayrıca mesleki kıdemi 21 yıl ve üzerinde olan yöneticilerin entelektüel uyarım düzeylerinin meslekteki kıdemi 10 yıldan az olan yöneticilere göre daha yüksek olduğu belirlenmiştir. Liderlik davranışı alt boyutlarında ise ekstra çaba, etkililik ve memnuniyet boyutlarının her üçünde de meslekteki kıdemi 21 yıl ve üzeri olan yöneticilerin ortalamasının meslekteki kıdemi 10 yıldan az olan yöneticilere göre anlamlı derecede daha yüksek olduğu saptanmıştır. Bu bulguların tam aksine olarak Üstün (2014) mesleki kıdem ile dönüşümcü liderlik ve liderlik davranışı alt boyutları arasında anlamlı bir ilişki bulmazken, etkileşimli liderlik ile mesleki kıdem arasında anlamlı ilişki olduğunu saptamıştır. Araştırmanın bu bulguları genel olarak değerlendirilecek olursa mesleki kıdemi daha yüksek olan yöneticilerin olumlu liderlik davranışlarının daha çok ön plana çıktığı görülmektedir. $\mathrm{Bu}$ durumun şüphesiz kıdemli yöneticilerin gerek mesleki gerekse de idari olarak daha tecrübeli olmasından kaynaklandığı, tecrübeli akademisyenlerin üniversitelerdeki akademik ve idari işleyişe olan hâkimiyetlerinin olumlu liderlik davranışlarını sergilemelerinde olumlu yönde etkili olduğu düşünülmektedir.

Çalışmada akademik unvan açısından doçent unvanında bulunan yöneticilerin ekstra çaba ve etkililik puanlarının öğretim görevlisi unvanını taşıyan yöneticilere göre anlamlı derecede daha yüksek olduğu saptanmıştır. Aynı zamanda profesör unvanına sahip olan yöneticilerin etkililik puanlarının ögretim görevlisi unvanına sahip yöneticilere göre anlamlı derecede daha yüksek olduğu da belirlenmiştir. Üstün (2014) tarafından yapılan çalışmada ise, akademik unvanın çoklu liderlik alt boyutları üzerinde anlamlı bir etkisinin olmadığı tespit edilmiştir. Araştırmanın bu bulgularının sebebi olarak, doçent ve profesör unvanına sahip olan akademisyenlerin öğretim görevlisi akademisyenlere göre meslek hayatlarında daha çok idari görev almış olabilecekleri ve bu sayede üniversitelerdeki akademik ve idari işleyişi konusunda daha tecrübeli olmaları söylenebilir.

Araştırmanın son bulgusuna göre, sağlık hizmetleri meslek yüksekokul müdürlerinin atfedilen ideal etki, telkinle güdüleme ve etkililik puanlarının hem müdür yardımcılarına hem de bölüm başkanlarına göre anlamlı derecede daha yüksek ve Laissez Faire puanlarının ise daha düşük olduğu tespit edilmiştir. Ekstra çaba ve memnuniyet alt boyut puanlarında ise sadece müdürler ile bölüm başkanları arasında farklılık belirlenmiş, müdürlerin ekstra çaba ve memnuniyet ortalama puanlarının bölüm başkanlarına göre anlamlı derecede daha yüksek olduğu saptanmıştır. Çalışmanın bu bulgusuyla paralel bir biçimde Keklik (2012) çalıșmasında, liderliğin bütün alt boyutlarında idari görev değişkeni açısından anlamlı farklılıklar olduğunu belirlemiștir. Araştırmanın bu bulguları değerlendirildiğinde ise meslek yüksekokullarında idari olarak en yetkili kişi olan müdürlerin olumlu liderlik davranışlarının daha ön plana çıkmasının önemli ve olumlu bir sonuç olduğu düşünülmektedir.

www.turkishstudies.net/social 


\section{Sonuç ve Öneriler}

Türkiye'de Sağlık Hizmetleri Meslek Yüksekokullarında görev alan yöneticilerin liderlik stiline yönelik alg1 düzeylerini tespit etmek amacıyla yapılan bu çalışmada önemli olduğu düşünülen sonuçlar elde edilmiştir. Üniversiteler bilimsel ve doğru bilginin üretiminde, üretilen bilginin gerçek hayat süreçlerinde uygulanmasında ve tüm bu süreçleri yürüten nitelikli bilim insanlarının yetişmesinde en önemli rolü oynamaktadır. Bu açıdan üniversitelerin eğitim kalitesini belirlemeye ve bunu etkileyen faktörlere yönelik yapılan çalışmalar büyük önem arz etmektedir. Üniversitelerde bulunan sağlık hizmetleri meslek yüksekokulları da söz konusu amaçlara hizmet edebilmek ve sağlık sektörüne kalifiye ve nitelikli sağlık çalışanları yetiştirebilmek için faaliyet göstermektedirler. Şüphesiz bir kurumun amaçlarına ulaşabilmesi ancak dinamik, modern ve etkili bir yönetimin varlığıyla mümkün olabilecektir. Böyle bir yönetimin sağlanabilmesi ise güçlü, modern ve dönüşümcü bir lider ile mümkündür. Üniversitelerde idari görev yapan akademik personel, kurumun akademik ve idari işleyişinden tümüyle sorumlu olmakla birlikte ders içeriklerinin ve akademik faaliyetlerin belirlenmesi gibi eğitim-öğretim politikalarının geliştirilmesi ve yürütülmesi aşamalarında da yetki sahibidir. Bu anlamda adeta idarecisi oldukları kurumda lider konumundadırlar. $\mathrm{Bu}$ çalışma, bu düşüncelerden hareket edilerek sağlık hizmetleri meslek yüksekokullarında akademik ve idari işleyiş üzerinde önemli yetki ve sorumluluğu olduğu düşünülen idarecilere yönelik olarak gerçekleştirilmiştir.

Araştırmanın tüm bulguları göz önüne alınarak genel bir sonuca ulaşıldığında, sağlık hizmetleri meslek yüksekokulu yönetim kadrosunda yer alan akademisyenlerin liderlik davranışı, dönüşümcü liderlik ve etkileşimli liderlik düzeyleri genel olarak yüksek düzeyde gözlenmiştir. Bu bağlamda yöneticilerin genel olarak değişim ve gelişime açık, pozitif yaklaşım içerisinde bir liderlik profiline sahip oldukları görülmüştür.

$\mathrm{Bu}$ tip çalışmaların daha geniş bir örneklemle daha kapsamlı olarak farklı fakülte ve meslek yüksekokullarında yürütülmesinin faydalı olacağı düşünülmektedir. Yapılacak yeni çalışmalarla gerek üniversitelerde gerekse de üniversitelerin alt birimlerinde yönetim kadrosunda yer alan akademisyenlerin liderlik stillerinin belirlenmesinin ve farklı değişkenlerle ilişkisinin sorgulanmasının da literatüre katkı sağlayacağı düşünülmektedir.

\section{Kaynakça}

Acar, A.Z. (2013). Farklı örgüt kültürü tipleri ve liderlik tarzları ile örgütsel bağlılık arasındaki ilişki: lojistik işletmelerinde bir araştırma. İ̧̧letme Araştırmaları Dergisi, 5(2), 5-31.

Akbolat, M., Işık, O. \& Yımaz, A. (2013). Dönüşümcü liderlik davranışlarının motivasyon ve duygusal bağlılığa etkisi. Uluslararast İktisadi ve İdari İncelemeler Dergisi, 6(11), 35-50.

Arı, G.S. (2003). Yöneticiye duyulan güven örgütsel bağl1lı̆ı artırır mı?. Gazi Üniversitesi Ticaret Turizm Eğitim Fakültesi Dergisi, 2, 17-36.

Arslantaş, C. \& Pekdemir, I. (2007). Dönüşümcü liderlik, örgütsel vatandaşlık davranışı ve örgütsel adalet arasındaki ilişkileri belirlemeye yönelik görgül bir araştırma. Sosyal Bilimler Dergisi, 1, 261-286.

Atılgan, F. (2013). Büro yönetimi ve yönetici asistanlı̆̆ 1 programında okuyan öğrencilerin liderlik tarzlarına ilişkin eğilimlerinin analizi muğla üniversitesi örneği. Süleyman Demirel Üniversitesi Sosyal Bilimler Enstitüsü Dergisi, 1, 268-279.

Aydın, A., Sarıer, Y. \& Uysal, Ş. (2013). Okul müdürlerinin liderlik stillerinin, öğretmenlerin örgütsel bağlılı̆̆ına ve iş doyumuna etkisi. Kuram ve Uygulamada Ĕgitim Bilimleri, 13(2), 795-811. 
Barbuto, J.E. (2005). Motivation and transactional, charismatic, and transformational leadership: a test of antecedents. Journal of Leadership and Organizational Studies, 11(4), 26-40.

Barlı, Ö. (2010). Davranış bilimleri ve örgütlerde davranış. Genişletilmiş ve Geliştirilmiş 4. Baskı, Aktif Yayıncilik.

Bass, B.M. \& Steidlmeier, P. (1999). Ethics, character and authentic transformational leadership behavior. Leadership Quarterly, 10(2), 181-217.

Bass, B.M. (1997). Personal selling and transactional/transformational leadership. Journal of Personal Selling and Sales Management, 17(3), 19-28.

Bass, B.M. \& Avolio, B.J. (1993). Transformational leadership: Aresponse to critiques. In M. M. Chemers, R. Ayman (Eds.), Leadershiptheory and research: Perspectives and directions SanDiego, CA: Academic Press, 49-80.

Buluç, B. (2009). İlköğretim okullarında bürokratik okul yapısı ile okul müdürlerinin liderlik stilleri arasındaki ilișki. Eğitim ve Bilim, 34(152), 71-86.

Cansoy, R. \& Polatcam, M. (2019). The relationship between school principals' leadership and teachers' organisational commitment: a systematic review. Bartin University Journal of Faculty of Education, 8(1), 1-31. http://dx.doi: 10.14686/buefad.441189

Cemaloğlu, N. \& Okçu, V. (2012). İlköğretim okulu yöneticilerinin liderlik stilleri ile öğretmenlerin yıldırma (mobbing) yaşama düzeyleri arasındaki ilişki. Uşak Üniversitesi Sosyal Bilimler Dergisi, 5(3), 227-228.

Çakınberk, A. \& Demirel, E.T. (2010). Örgütsel bağlılı̆̆ın belirleyicisi olarak liderlik: Sağlık çalışanları örneği. Selçuk Üniversitesi Sosyal Bilimler Enstitüsü Dergisi, 24, 103-119.

Demir, C., Yılmaz, M. K. \& Çevirgen, A. (2010). Liderlik yaklaşımları ve liderlik tarzlarına ilişkin bir araştırma. Alanya İşletme Fakültesi Dergisi, 2(1), 130-142.

Durak, İ. (2012). Korku kültürü ve örgütsel sessizlik. Ekin Yayınc1lık.

Hemedoğlu, E. \& Evliyaoğlu, F. (2012). Çalışanların dönüşümcü liderlik algılarının örgütsel bağl1lıkları üzerindeki etkilerinin incelenmesi. Işsletme Araştırmaları Dergisi, 4(1), 59-77.

Karahan, A. (2008). Hastanelerde liderlik ve örgütsel bağlllık arasındaki ilişkinin incelenmesi. Afyon Kocatepe Üniversitesi Sosyal Bilimler Dergisi, 10(1), 145-162.

Kartal, M. \& Bardakçı, S. (2019). Tutum ölçekleri. Akademisyen Yayınevi.

Keklik, B. (2012). Sağlık hizmetlerinde benimsenen liderlik tiplerinin belirlenmesi: özel bir hastane örneği. Afyon Kocatepe Üniversitesi, İ̈BF Dergisi, 14(1), 73-93.

Kırel, Ç. (2001). Liderlik davranış biçimleri konusuna yeni bir yaklaşım: Karizmatik liderlikten dönüşümsel liderliğe. Anadolu Üniversitesi Sosyal Bilimler Fakültesi Dergisi, 1, 43-60.

Kırkpınar, S. \& İşcan, Ö.F. (2018). Liderlik tarzlarının iş tatmini ve örgütsel bağlılığa etkileri. Hacettepe Sağlık İdaresi Dergisi, 21(1), 65-85.

Koçel, T. (2007). İşletme yöneticiliği. Arıkan Yayınları.

Koontz, H., O'Donnell, C. \& Weichrich, H. (1999). Essential of management. MacGraw Hill Inc.

Kul, M. \& Güçlü, M. (2010). Okul yöneticilerinin liderlik stilleri ile beden eğitimi öğretmenlerinin örgütsel bağlılıkları arasındaki ilişki. Uluslar arası İnsan Bilimleri Dergisi, 7(2), 10-23.

Liu, Y. (2015). The review of empowerment leadership. Open Journal of Business and Management, 3, 476-482. http://dx.doi: 10.4236/ojbm.2015.34049 
Örgev, C. \& Sütlü, E.S. (2018). Sağlık çalışanlarının hizmetkar liderlik algılarının örgüt iklimi ve örgütsel bağl1lık üzerine etkileri: Bir kamu hastanesi örneği. Sağllk Akademisyenler Dergisi, 5(1), 47-53. http://dx.doi:10.5455/sad.13-1512992092

Örücü, E. \& Teker, S.K. (2014). Hastanelerde liderlik ve örgütsel bağlllık arasındaki ilişkinin incelenmesi: Sağlık sektöründe bir araştırma. Yönetim ve Ekonomi Araştırmaları Dergisi, 24, 73-90. http://dx.doi:10.11611/yead.234393

Polat, Ş.B. (2012). Yükseköğretim kurumlarında kurum içi iletişim anlayışı ve paydaş memnuniyeti ilişkisi: akademik personel perspektifinde bir çalışma. Yüksek Lisans Tezi, Maltepe Üniversitesi Sosyal Bilimler Enstitüsü.

Scandura, T.R. \& Williams, E.A. (2004). Mentoring and transformational leadership: The role of supervisory career mentoring. Journal of Vocational Behavior, 65(3), 448-468.

Serinkan, C. (2002). Dönüşümcü ve etkileşimci liderlik tarzları ve tepe yöneticileri için önemi. Maltepe üniversitesi I.I.B.F Ekonomik, Toplumsal ve Siyasal Analiz Dergisi, 1(2), 73-89.

Stewart, J. (2006). Transformational Leadership, An evolving concept examined through the works of burns, bass, avolio and leithwood. Canadian Journal of Educational Administration and Policy, 54, 1-29.

Şirin, E. F. \& Yetim, A.A. (2009). Beden eğitimi ve spor yüksekokulu yöneticilerinin dönüşümcü liderlik stiline ilişkin yönetici algıları, Niğde Üniversitesi Beden Ĕgitimi ve Spor Bilimleri Dergisi, 3(1), 69-84.

Üstün, F. (2014). Spor eğitimi veren yükseköğretim kurumlarındaki yöneticilerin liderlik stili algıları ve örgütsel sessizlik yaşama düzeyi. Doktora Tezi, Gazi Üniversitesi Sağlık Bilimleri Enstitüsü.

Yavuz, E. (2009). İş görenlerin dönüşümcü liderlik ve örgütsel bağlllık ile ilgili tutumlarına yönelik bir araştırma. İşletme Araştırmaları Dergisi, 1(2), 54-55. 